\author{
Olena BULATOVA, \\ Yurii CHENTUKOV, \\ Illia CHENTUKOV
}

\title{
INTEGRATION PROCESSES AND GLOBAL REGIONS
}

\begin{abstract}
This article deals with changes of a spatial structure of the world economy, which has complex and heterogeneous hierarchy. It specifies that multipurposeness and complex structuring are becoming global signs of regionalization processes and highlights the enhanced role of regional competitiveness within the context of global transformation. The emphasis is laid upon the objectiveness of the global regionalization process, which characterizes processes of the world economy development whilst global regions are becoming its main system elements. This paper stresses that global regionalization development is reflected through a new global space structure. It suggests a methodic toolbox of comprehensive assessment of regional integration development processes with due consideration of various aspects (trade, industrial and market integration), which provides for a comparative analysis of global regions ' development or of certain integration associations according to the development level of integration processes on the basis of suggested integrated index.
\end{abstract}

(C) Olena Bulatova, Yurii Chentukov, Illia Chentukov, 2018.

Bulatova Olena, Doctor of Economic Sciences, Professor, Mariupol State University. Chentukov Yurii, Doctor of Economic Sciences, Professor, Mariupol State University. Chentukov Ilia, Candidate of Science in Economics, Mariupol State University. 


\section{Key words:}

Region, global region, regionalization, global regionalization, new regionalism.

JEL: F02.

\section{Conceptual framework of the world economy regionalization}

The development of powerful international regions, emerging in the global economy on an integrated basis, allows identifying global signs of regionalization processes. On the other hand, the regions themselves have a direct impact on global development, altering the global space structure of the world economy, its actors, etc. Formation of regional space under the conditions of globalization is also influenced by the fact that the economic interests of business entities do not necessarily have to coincide with the existing administrative-territorial division, which, in its turn, creates special prerequisites for the development of regionalism based on common interests of territorial entities.

Under the influence of the modern world economy development trends, a transition from an old regionalism (where the internal-oriented protectionist component of regional development is prevalent) to a new regionalism took place (which is characterized by both the liberalization of trade relations as well as the emergence of other deeper forms of integration interaction).

Under current conditions the static concept of regions no longer corresponds to the erratic conditions of world economic development and steps back from the territorial (geographical, physical) definition of the region to approach the functional one (institutional, integrative) due to the functioning of two interrelated processes: firstly, processes of intraregional changes and, secondly, processes of the direct formation of the region that determine its external boundaries.

The territorial factor is an important element of a competition, but in terms of active development of the network economy, information and communication technologies, and its influence on the formation of competitive advantages is minimized. M. Enright (2000), C. Karlsson (2008), J. Pelkman (2006), M. Porter 
(1998) paid attention to it in their scientific researches. From the standpoint of the new economic geography (P. Krugman, E. Venaylz, M. Fujita) (1999) comparative advantages in spatial development are provided not only by the territorial factor (location, allocation of resources, etc.), which along with the development of infrastructure diminishes its influence. When shaping comparative advantages, factors associated with the activities of society (agglomeration effect, human capital, institutions, etc.) are also of great importance. These factors become crucial in the processes of modernizing the economy. The fundamental factors of modern spatial development are as follows:

- spatial population concentration and urban agglomerations development (density),

- economic distance, which is determined not only by remoteness from the markets, but also by the level of infrastructural development, the low level of which increases transaction costs (distance),

- institutional barriers in general that reduce the mobility of commodities, production factors, restrict access to public goods that develop human capital (division) (2009).

Modern spatial structure of the world economy has a complex and heterogeneous hierarchy. The main taxonomic levels are interstate, state, supranational that cover the corresponding levels of regions (local-, micro-, meso-, macro-, mega-, meta-level). Since the regions defined by these levels vary in scale and socio-economic level, all forms of interaction will vary and have a certain institutional basis, and, accordingly, undergo the impact of globalization differently, and on the other hand, directly affect the development of the global integration. A. Scott, M. Storper (2003; 2000) pay attention to enhancing role of regions in contemporary international relations and note that regions are becoming independent actors. Subsequently, F. Cheru's future contributions (2000) will determine the nature and scale of local transformations.

The purpose of the research paper is to develop modern methodical toolbox for measuring integration processes. 


\section{Global regionalization as an objective process}

In terms of further global integration development, the regionalization processes acquire new qualitative attributes related to the formation of global regions in the world economy, based on common interests of certain actors of international economic relations. Global signs of regionalization processes in the modern world economy system are multipurposeness of global regionalization; a complex structured interaction network developing at different regional levels and embracing states, societies, and businesses; enhancing the role of regional competitiveness in the framework of global transformations.

Global regionalization is an objective process defining the processes of the world economy development, based on the redistribution and deepening of dialectically interconnected integration processes at global and regional levels, whilst global regions, developing on a functional (institutional) basis, are taking the position of its main system elements. The global regionalization development is reflected in a qualitatively new spatial world structure.

As the network economy develops, the formation of regions is no longer attached to the specific territory where new forms of spatial organization are created. Common interests of certain subjects of international economic relations, their multipurposeness and the complex network of interaction at different regional levels contributed to the emergence of global regions.

Enjoying the benefits of the global market to the greatest extent by means of authorization of new organizational forms of regional integration, the new regionalism development fosters deeper integration and helps transforming the global system, where both the adaptation of national policies as well as the mitigation of governmental intervention impact take place (Hettne,1999). Some integration initiatives result in a combination of elements of both old and new regionalism. The so-called hybrid regionalism is used to strengthen cooperation, to develop a more flexible development mechanism and not necessarily to be institutionalized (Grimmel, June 2018). In addition, there is an increase in the number of regional trade agreements that are concluded between distant countries, while their cooperation development is based on strategic partnership principles that are not necessarily linked to the geographical proximity factor and presence of common borders.

The number of regional integration agreements concluded in the world constantly increases (Fig. 1). And if the first wave of the regional integration initiatives development (1950-1960s) was primarily due to the continental integration development that spread through European countries, then the second wave (1980-1999) engulfed all the other regions of the world that were arduously sign- 
ing integration agreements, where at least $60 \%$ were of interregional nature (World Trade Report, 2011, pp. 51-54). A record number of regional trade agreements, which are in force today, were concluded in the early 21 st century which amounted to 208 agreements, making up $72 \%$ of total number of agreements in force. Developing states have been particularly active in this process, which aside from promoting conclusion of South-South agreements, also expanded the range of their integrating states among developed states (SouthNorth agreements). As of mid-2018, the total number of notified regional trade agreements, the ones notified by the WTO constituted 673, including 459 (Online resource) ones in force.

Fig. 1

\section{Regional trade agreements conclusion dynamics (cumulative result)}

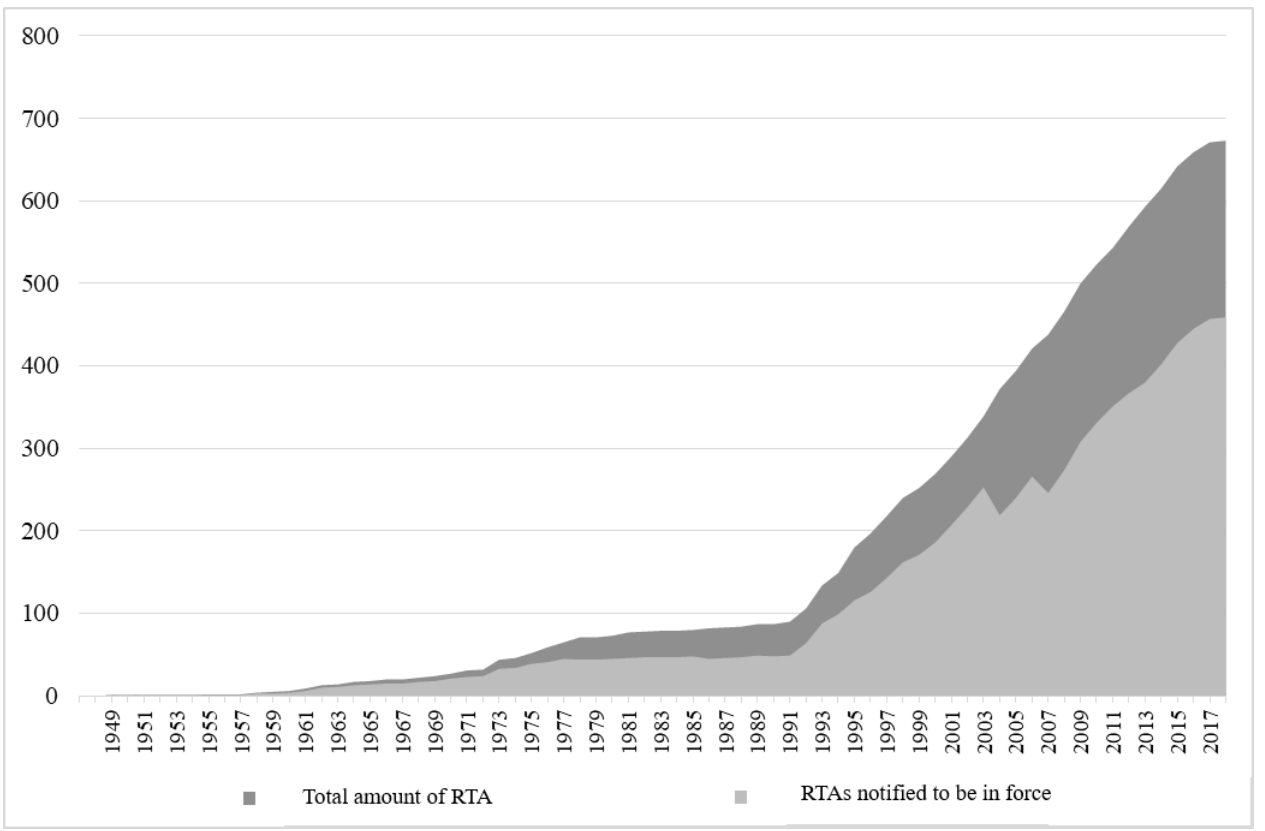

Among the reasons for such a rapid growth of regional integration initiatives, the author singles out the following. Against the background of the gradual moderation of the development of a multilateral regulatory mechanism for trade and economic relations, states have increasingly used a liberalization mecha- 
nism under the relevant regional agreements, which have become an integral component of national trade policies. Due to the fact that it is unlikely to resolve some issues by means of certain WTO regulations (since they are beyond the WTO rules), states have begun to apply regional agreements that in addition to concerning the issues of mutual trade also became more elaborated and complex in terms of context and covered the issues of capital flow, small business, intellectual property, competition policy, environmental regulations and labormanagement relations. The rapid dynamics of the integration initiatives development is, in fact, an indicator of practical implementation of the globalization trends of national governments in executing relevant policies that ensure both free accesses to the market as well as boosting the competitiveness of states. Besides, it is necessary to take into account changes that are related to the complication of global chains. While trying to provide more efficient ways of producing their products, multinational companies split traditional vertically integrated production models into separate stages or functions that increase the fragmentation of the world production, affect changes in trade policy, integration development strategies of states etc.

\section{Methodical tool for a comprehensive assessment of the regional integration development processes}

The key issue in the methodology of the integration processes research is the formation of system of indicators of regional economic integration that comprehensively and thoroughly reflects the nature and specificity of the development of these processes. The methodical toolbox for a comprehensive assessment of the regional integration processes development envisages the following: the creation of an aggregated index of the regional integration processes development, which consists of a system of individual integration processes development indicators; carrying out a comparative analysis of the development of global regions or of individual integration associations according to the level of integration processes development on the basis of the proposed aggregated index; carrying out a factor analysis, which allows determining which indicators or groups of indicators determine the overall level of integration processes development in regions or in separate integration associations; the creation of economic and mathematical models of the dependence of socio-economic development level of global regions on the level of integration processes development.

Based on the analysis of existing indicators reflecting various aspects of the development and integration processes intensity, namely, regional (global regions) and institutional (integration associations), the use of the aggregated inte- 
gration index is suggested (aggregated integration index (All)), which is formed by means of aggregation of three composing sub-indices:

- The trade integration index

- The production integration index and

- The market integration index.

The application of the aggregated integration index apart from enabling to carry out a comprehensive assessment of integration processes development level within a certain regional integration association, also allows to conduct a comparative analysis of their development within the framework of global regions of the world. The structure of the aggregated integration index is presented in Table 1.

\section{Table 1}

Structure of the aggregated integration index

\begin{tabular}{|c|c|c|}
\hline \multicolumn{3}{|c|}{ Aggregated integration index(AIl) } \\
\hline $\begin{array}{c}\text { Trade integration index } \\
\text { (TII) }\end{array}$ & $\begin{array}{c}\text { Production integration } \\
\text { index (PII) }\end{array}$ & $\begin{array}{c}\text { Market integration index } \\
(\text { MII) }\end{array}$ \\
\hline $\begin{array}{c}\text { The volume of intrare- } \\
\text { gional trade (turnover) } \\
\text { per capita, USD }\end{array}$ & $\begin{array}{c}\text { Investment volumes per } \\
\text { capita, USD }\end{array}$ & $\begin{array}{c}\text { The GDP of integration } \\
\text { association per capita, } \\
\text { USD }\end{array}$ \\
\hline $\begin{array}{c}\text { Share of intraregional } \\
\text { trade, \% }\end{array}$ & $\begin{array}{c}\text { Share of integration as- } \\
\text { sociation in the world in- } \\
\text { vestment volume, } \%\end{array}$ & $\begin{array}{c}\text { Share of integration as- } \\
\text { sociation in the world } \\
\text { GDP, \% }\end{array}$ \\
\hline $\begin{array}{c}\text { Share of integration as- } \\
\text { sociation in the world } \\
\text { trade, \% }\end{array}$ & $\begin{array}{c}\text { Financial openness in- } \\
\text { dex }\end{array}$ & $\begin{array}{c}\text { Share of integration as- } \\
\text { sociation population in } \\
\text { the world population, \% }\end{array}$ \\
\cline { 1 - 1 } $\begin{array}{c}\text { Intraregional trade inten- } \\
\text { sity index }\end{array}$ & Share of ICT intrare- \\
gional export, \% & Concentration index \\
\cline { 1 - 1 } $\begin{array}{c}\text { Intraregional and ex- } \\
\text { traregional trade index }\end{array}$ & Diversification index \\
& Complementarity index \\
\hline
\end{tabular}

The presented integral indicator is formed by aggregation of three composing sub-indices, namely the trade integration, production integration and market integration indices. Aggregation was carried out on the basis of the application of the geometric mean: 


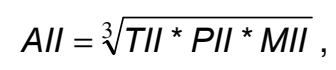

where All is the aggregated integration index,

TII - trade integration index,

RII - production integration index,

MII - market integration index.

Each composing sub-index of the aggregated integration index is formed by means of combination of individual indicators that reflect different aspects of the integration processes development. The feature of the included indicators is that they are represented by relative values (intensity, structure, indices), therefore, when estimating, the size and socio-economic potential of the development of objects subject to comparative multidimensional assessment is taken into account (global regions, integration associations).

Similar to the general aggregated integration index, the composing subindices are calculated on the basis of the average geometric aggregation of single indices (1.2-1.4).

$$
\begin{array}{r}
T I I=\sqrt[5]{I T_{P C j} \times d_{I T j} \times d_{X j} \times I T I I_{j} \times M T I I_{j}} . \\
P I I=\sqrt[4]{F D I_{P C j} \times d_{F D I j} \times I F I_{j} \times d_{X I C T j}} . \\
M I I=\sqrt[4]{G D P_{P C j} \times d_{G D P j} \times d_{N j} \times C I \times D I \times T C I} .
\end{array}
$$

From the standpoint of the calculation methodology, it should be noted that (1.2) - (1.4) do not employ output values of indicators, but rather their standardized estimates. Standardization of parameters is one of the methods of bringing the heterogeneous indicators to the comparative form with their subsequent inclusion in the multidimensional (integral) indicators. The study employed one of the most common methods of standardization, which involves comparing the values of each of the single parameters researched, with its maximum and minimum values for the sample of objects. In this case, standardized estimates of the indicators are calculated according to the formulas (1.5) for incentive indicators and (1.6) for disincentive indicators:

$$
\begin{gathered}
P_{i j}=\frac{x_{i j}-x_{\min }}{x_{\max }-x_{\min }} . \\
P_{i j}=\frac{x_{\max }-x_{i j}}{x_{\max }-x_{\min }} .
\end{gathered}
$$

Approbation of the proposed toolbox for comprehensive assessment of the integration processes development level allowed to calculate the integral indica- 
tors in the framework of the regional approach in the global regions of the world and in the context of main integration associations and to determine the ranking of the groups by the integration processes development level. The results indicate that the EU (aggregated integration index equals 0.547), NAFTA, FTAA, ASEAN and APTA (Figure 2) can be characterized as ones with the highest level of integration cooperation development. Among the integration associations in the African region, SADC, MRU and WAEMU are the most developed ones in terms of the close integration cooperation.

Fig. 2

\section{Aggregated integration index}

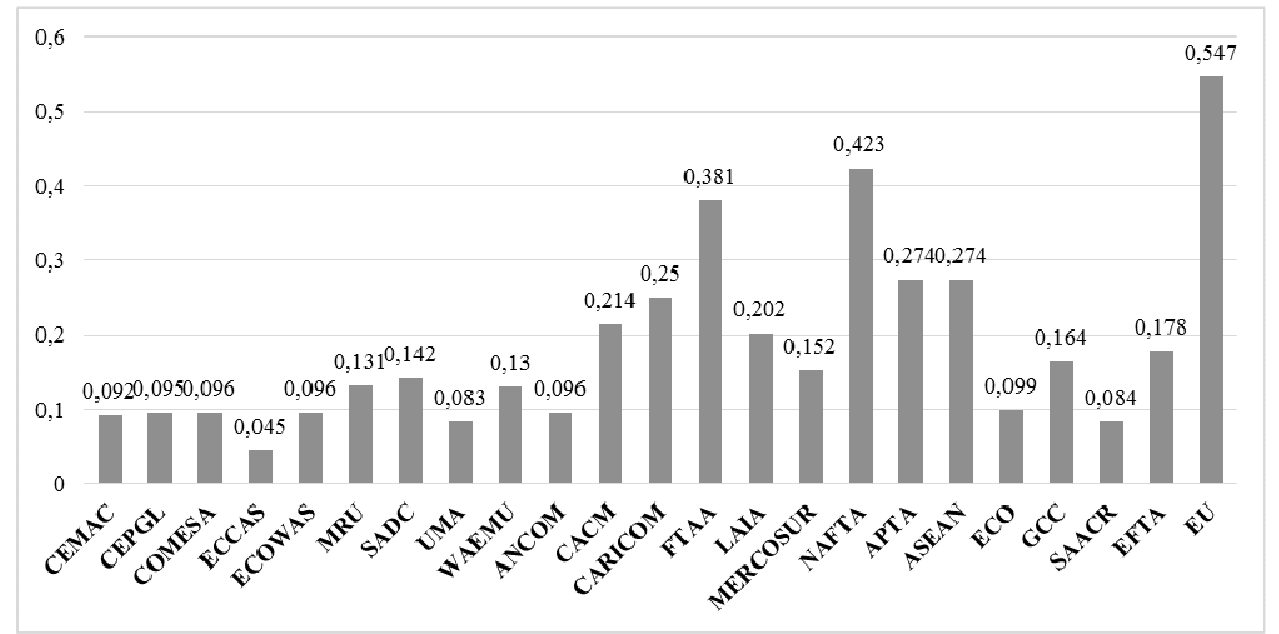

The highest level of close trade cooperation is peculiar of the EU (0.524), CARICOM (0.378), WAEMU (0.289), FTAA (0.287), NAFTA (0.267), level of production integration development - EFTA (0.563), the EU (0.443), NAFTA (0.389), FTAA (0.345), ASEAN (0.288), degree of market integration - NAFTA (0.732), ASEAN (0.726), the EU (0.704), EFTA (0.567) and FTAA (0.558). The calculation of aggregated indices in the dynamics for the period 1995-2013 allowed revealing certain patterns of integration processes development intensity within the groups of global regions of the world, which allowed building regional ratings according to the level and intensity of the integration processes development (Fig. 3). 
Fig. 3

The ranking of regions of the world by the level of development of integration processes

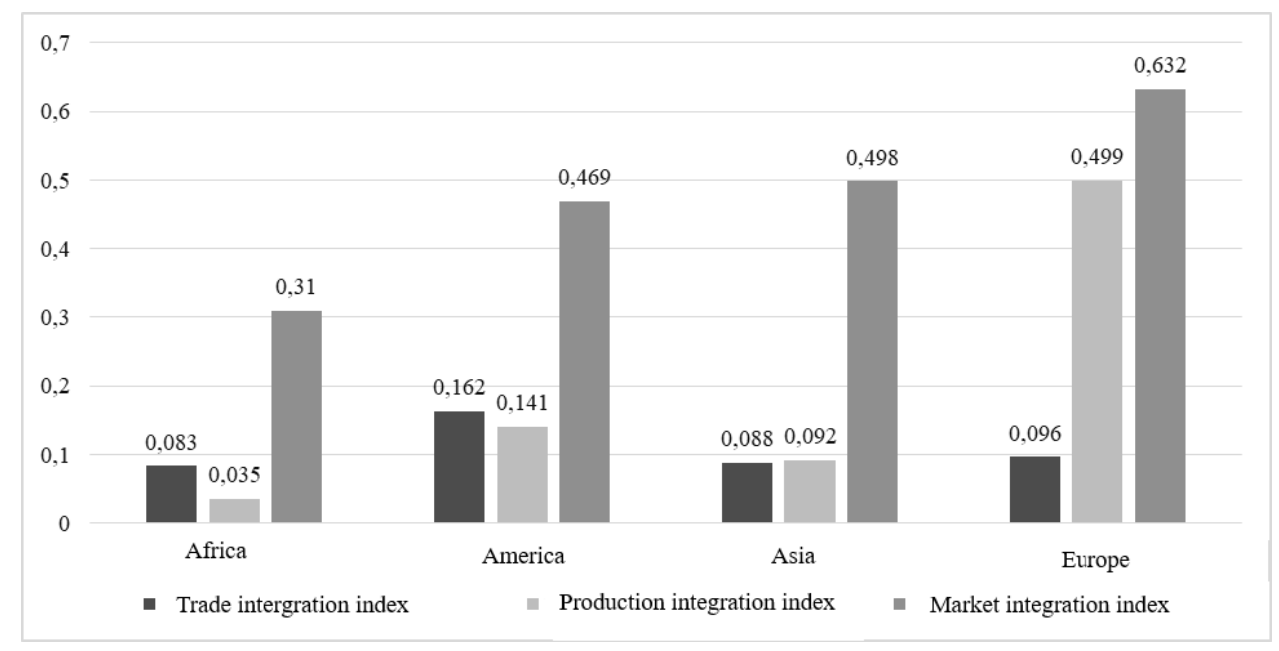

In terms of a regional approach, the European region is characterized by the highest intensity and closeness of integration cooperation the most (the aggregated index of integration, which is $0.312,41 \%$ higher than the same indicator in the American region (0.221), almost 2 times higher than the indicator of the aggregated integration index in the Asian region (0.159), 3.3 times higher than in Africa (0.096). The American region is characterized by the highest level of trade integration (which is $69 \%$ higher than the European one, almost twice higher than the Asian one). The highest level of production integration was found in the European region, which 3.5 times higher than the corresponding US estimates, and 5.4 times higher than Asian ones. The dynamics of the production integration index is most closely related to the aggregated integration index variation for all regions. 


\section{Conclusion}

Calculation of general indicators of the integration processes development enables to obtain a comprehensive assessment of the integration interaction level taking into account various aspects (trade integration, production integration, market integration); to carry out a comparative analysis of the integration processes development within the global regions and integration associations; to determine the global regions development patterns under the conditions of enhanced integration processes and to assess the impact of integration processes on changes taking place in the global environment.

The suggested methodical toolbox for a comprehensive assessment of the regional integration processes development envisages the following:

The creation of an aggregated index of the regional integration processes development;

Carrying out a comparative analysis of the development of global regions or individual integration associations according to the level of development of integration processes on the basis of the aggregated index suggested;

Conducting a factor analysis, which allows finding out which indicators determine the overall level of integration processes development by regions or by individual integration associations;

The construction of economic and mathematical models of the dependence of the socio-economic development level of global regions on the integration processes development level.

The global regionalization process creates an institutional and political basis for the profound integration of markets and the elimination of trade barriers, and integration mechanisms are becoming an important supplement to liberalization within the multilateral trading system. Regionalization should be classified as a process of an empirical nature the research of which requires an interdisciplinary approach that will allow developing new results from regionalization studies in terms of regional diversification and competitiveness in the context of global transformations taking place in the global economy.

Integration processes, acquiring global scope, embrace the states of all regions of the world, regardless of the level of socio-economic development, degree of involvement in international division of labor system. The greatest effect of deepening integration cooperation is developed states, and associations with their participation determine the vectors of contemporary world economic development, retaining a monopoly position in the market for knowledge-intensive and innovative products and services. Developing states, by engaging in global integration processes, solve the issues of strengthening their own competitive posi- 
tions in the system of world economic relations, accelerating economic growth, raising the level of welfare and income of the population, optimizing the structure of production and exports, ensuring growth and consolidation of their positions in system of world economy.

\section{References}

1. Cheru, F. (2000). Transforming our common future: the local dimensions of global reform. Review of International Political Economy. Vol. 7, No 2, pp. 353-368.

2. Enright, M. (1993). The geographical Scope of competitive Advantage. Stuck in the Region / Edited by E.Dirven, J. Groenewegen, S.van Hoff. Utrecht, pp.87-102.

3. Fujita, M. (1999). The Spatial Economy: Cities, Regions and International Trade. Fujita M., Krugman P.R., Venables A.J. MIT Press, Cambridge MA,. $640 \mathrm{p}$.

4. Grimmel, A. (June 2018). The Belt and Road Initiative: A Hybrid Model of Regionalism .Yuan Li. - Working Papers on East Asian Studies. №122. 22p. URL: https://www.uni-due.de/imperia/md/content/in-east/about/publications_ green_series/paper122-2018.pdf

5. Hettne, B. (1999). Globalism and New Regionalism/ Hettne Björn, Inotai András and Sunkel Osvaldo. New York: Macmillan, 308p.

6. Regional Trade Agreements Information System. WTO http://rtais.wto.org/ [Official website].

7. Karlsson, C. (2008). Handbook of research on cluster theory. Edward Elgar Publishing, $316 \mathrm{p}$.

8. Pelkmans, J. (2006). European integration: methods and economic analysis. Pearson Education, 480p.

9. Porter, M. (1998). Clusters and the new economics of competition. Harvard Business Review. Vol. 76 Issue 6. pp.77-90.

10. Reshaping economic geography (2009). World development report- Washington: The World Bank, DC, 383p.

11. Scott, A. J. (2003). Regions, globalization, development/ Allen J. Scott and Michael Storper // Regional Studies. vol. 37: 6\&7. pp 579-593.

12. Storper, M. Globalization, Localization and Trade (2000). / M. Storper // The Oxford Handbook of Economic Geography / Edited by Gordon L. Clark, 
Maryann P. Feldman, and Meric S. Gertler. Oxford (U.K.): Oxford University Press, pp. 146

13. World Trade Report 2011. The WTO and preferential trade agreements: from co-existence to coherence [Electronic resource]. Geneva: WTO Publications, 2011. 251p. World Trade Organization [Official website]. URL: www.wto.org/ enlish/res_e/booksp_e/anrep_e/ world_trade_report11_e.pdf

The article was received on August 6, 2018. 